\title{
側鎖末端シリル化ビスフェニルフルオレンーチタニアハイブリッド 薄膜の作製と屈折率に及ぼす側鎖長の影響
}

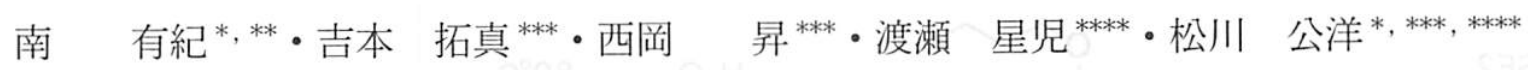
要旨

チタンアルコキシドと反応可能なアルコキシシリル基を有する側鎖末端ビスシリル化ビスフェニルフルオ レン誘導体は，エチレングリコール長の異なるビスフェノキシェチレングリコールフルオレンジアクリレー トに対して，末端をシリル化することによって合成した。これらとチタンテトラーn一ブトキシドを様々な 配合比で混合し，それらを光酸発生剤の存在下でスピンコート，紫外線照射することによって有機無機八イ ブリッド薄膜を作製した。チタニア含有量に依存した屈折率において，側鎖長の異なるビスシリル化ビスフェ ニルフルオレン誘導体により変化率が異なることから，側鎖間に空隙の存在が示唆された。

\section{1.はじめに}

フラットパネルディスプレイや近年急速な発展を遂げて いるタッチパネルなどには, 光学材料が多く搭載されてお り，それらの重要性はますます高まってきている。中であ 高屈折率材料は, 高性能化する表示デバイスなどの光学素 子に不可欠な素材となっている。高屈折率薄膜を作製する ための効果的な手法としては, $\mathrm{TiO}_{2}$ などの金属酸化物を 用いた有機無機ハイブリッドを挙げることができ, チタン アルコキシドを原料とするチタニアハイブリッドは精力的 に検討されている ${ }^{1 \sim 11}$ 。チタニアの屈折率は有機材料に比 ベ非常に高く, アナターゼ型で 2.55 , ルチル型で 2.62 で あり, ハイブリッド化することで有機材料のみでは得るこ とのできない屈折率特性を実現することができるので注目 されている。一方, 有機材料における高屈折率化の手法は 芳香環化合物の導入, フッ素を除くハロゲン元素の導入, 硫黄元素の導入が挙げられる。芳香環化合物の導入につい て, 我々はすでにビスフェノキシェタノールフルオレンジ

*大阪市立大学 大阪市住吉区杉本 3-3-138 $\mathbf{\text { T } 5 5 8 - 8 5 8 5}$

**(战)ソーラー 加西市中野町 $1174-1 \quad$ ₹ 675-2102

*** 大阪電気通信大学 安屋川市初町 18-8 $\quad$ 个 572-8530

*****大阪市立工業研究所

大阪市城東区森之宮 1-6-50 ₹ 536-8553

(原稿受付日: 平成 26 年 6 月 2 日)
アクリレートとチタニアー光硬化性シリカゾルの光重合に よる高屈折率ハイブリッド材料の調製を報告している ${ }^{12)}$ 。 さらに, ソ゚ルーゲル反応により調製したエポキシシルセス キオキサンとビスフェノキシェタノールフルオレンジグリ シジルエーテルとのハイブリッド材料は光酸発生剤を使用 した光カチオン重合で作製し，光学材料に応用可能な透明 かつ高屈折率なハードコート材料が得られることを確認し た ${ }^{13)}$ 。優れた光学特性を有するビスフェニルフルオレン 化合物を高屈折率な金属酸化物とハイブリッド化すること で，より高屈折率な材料を創製する事ができるむのと考え られる。しかし, ビスフェニルフルオレン化合物とチタン アルコキシドには相互作用がないため, 相分離を起こし八 イブリッド化することは不可能である。本研究では, 末端 にアクリル基を有するビスフェニルフルオレン誘導体への メルカプトプロピルトリメトキシシランの Michael 付加 反応で，アルコキシシリル基を導入する事で，チタンアル コキシドとの共有結合が可能なビスアルコキシシリル化合 物を合成し, チタニウムブトキシドとの光ゾルーゲル反応 で高屈折率を示す新規な有機無機ハイブリッド薄膜作製と 光学特性の検討を行った。

\section{2. 実験方法}

2.1 Michael 付加反応による末端ビスシリル化ビスフェ ニルフルオレン誘導体の合成

ビスフェノキシェタノールフルオレンジアクリレート （大阪ガスケミカル製；側鎖にエチレングリコールユニッ 


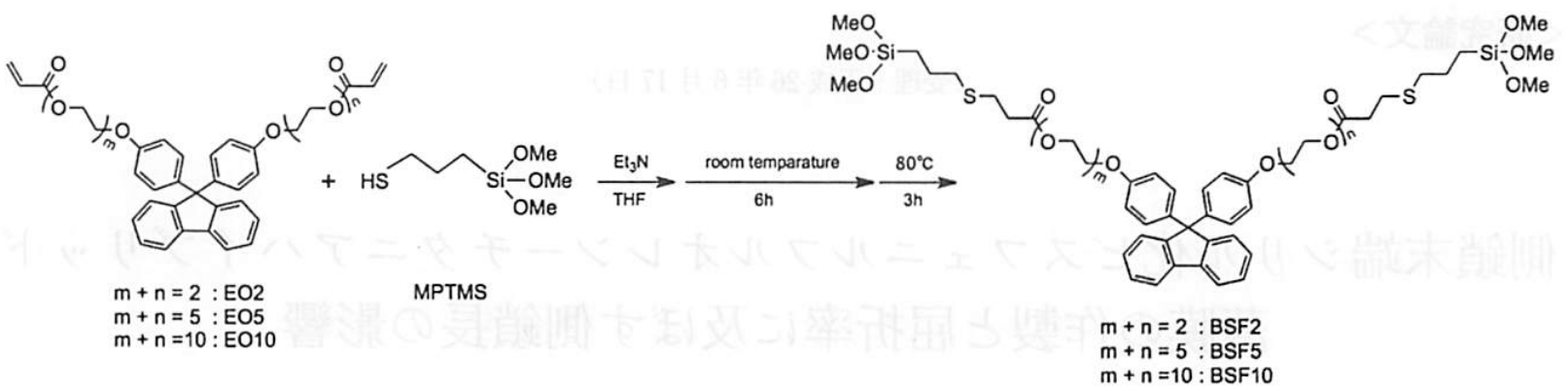

Scheme 1 Synthesis of BSF2, BSF5, and BSF10.

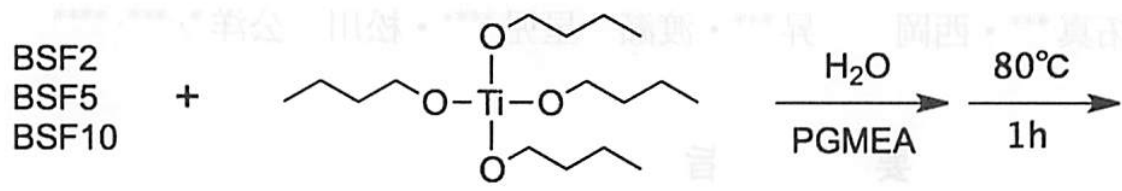

Titanium tetrabutoxide

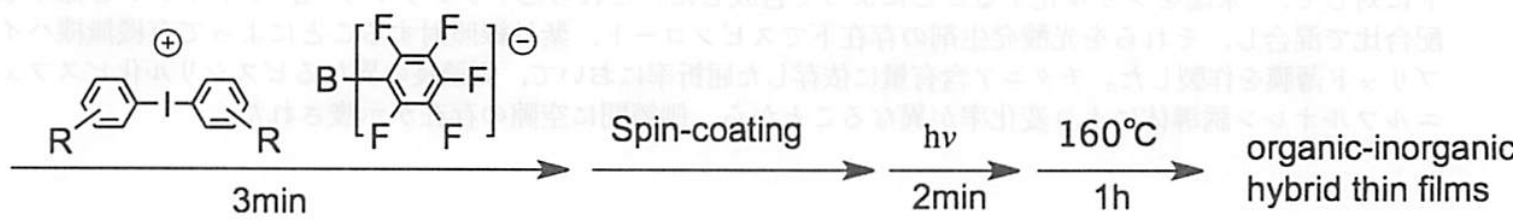

Scheme 2 Preparation of organic-inorganic hybrid thin films.

トを 2 つ含んでおり，以後，本論文中では $\mathrm{EO} 2$ と略す） を THF に溶解し，メルカプトプロピルトリメトキシシラ ン(MPTMS，東京化成工業製)を EO2 に対して 2.2 倍モ ルを量り入れ，さらに蒸留したトリェチルアミン（TEA， ナカライテスク製）をMPTMS と等モル量を添加した。

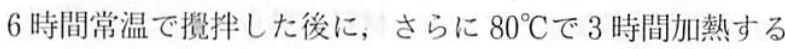
ことで，アクリル $\mathrm{C}=\mathrm{C}$ 結合へのチオール基の Michael 付加反応を行った。真空除去により低沸点未反応物および 溶媒を除去することで, BSF2 を合成した（Scheme 1)。 ビスフェノキシオリゴ (エチルオキシ) フルオレンジアク リレート (大阪ガスケミカル製) 側鎖に含まれるエチレン グリコールユニットが 5 及び 10 のものをそれぞれ EO5, EO10 と略し, 同様の手法にて Michael 付加反応を行い, 得られた反応物をそれぞれ BSF5, BSF10 とした。BSF2, 5,10 の生成はフーリエ変換赤外分光光度計 (NICOLET4700，サーモニコレー製）を用いて， FT-IR スペクトル を測定し確認を行った。また，核磁気共鳴装置（AL-300, 日本電子製）により， ${ }^{1} \mathrm{H}-\mathrm{NMR}$ スペクトルを測定するこ とで確認した。BSF2 の分子量は, 質量分析計 (JMS$600 \mathrm{H}$, 日本電子製) を用いて電界脱離質量分析 (FD-MS), 高速原子衝撃質量分析 (FAB-MS) で測定した。

\section{2 フルオレンーチタニアハイブリッド薄膜の作製}

ハイブリッド薄膜の作製は，プロピレングリコールモ， メチルエーテルアセテート（PGMEA，東京化成製）中で
溶解したシランカップリング剂（BSF2，BSF5，BSF10） とチタンテトラーnーブトキシド（和光純薬工業製）を様々

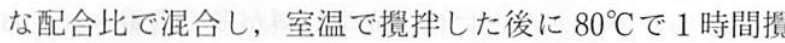
拌した。次に, 光酸発生剂 (PAG) であるジアリールョー ドニウム塩（SILCOLEASE UV CATA 211）を添加し， 3 分間筧拌した。得られたフルオレンーチタニアハイブリッ ド溶液は，スピンコーターを用いてスライドガラス上にコー ティングし, UV 照射 $\left(1610 \mathrm{~mJ} / \mathrm{cm}^{2}\right)$ を 2 分間行った後 に, $160^{\circ} \mathrm{C}$ で 1 時間加熱することでフルオレンーチタニア ハイブリッド薄膜を得た（Scheme 2)。ハイブリッド薄膜 の硬化は, フーリエ変換赤外分光光度計 (NICOLET-4700, サーモニコレー製）を用いて，FT-IR スペクトルを測定 し反応の確認を行った。ハイブリッド薄膜の透過率および ヘイズは紫外可視分光光度計 $(\mathrm{V}-560$, 日本分光製) に より測定した。屈折率は反射分光膜厚計（FE-3000，大 塚電子製）を用いて測定した。

\section{3. 結果と考察}

\section{1 末端ビスシリル化フルオレン誘導体の合成}

ビスフェニルフルオレン誘導体は, 芳香族多環化合物で あるフルオレンの 9 位に 2 つのフェニル基が結合した化学 構造をしている。1つの分子に 4 つの芳香環を含んでいる ので， 1.6 を超える高屈折率の光学材料として期待されて いる。この 2 つのェニル基は異なる方向を向いた“カル ド構造”という特殊な立体配置を有している。これにより， 

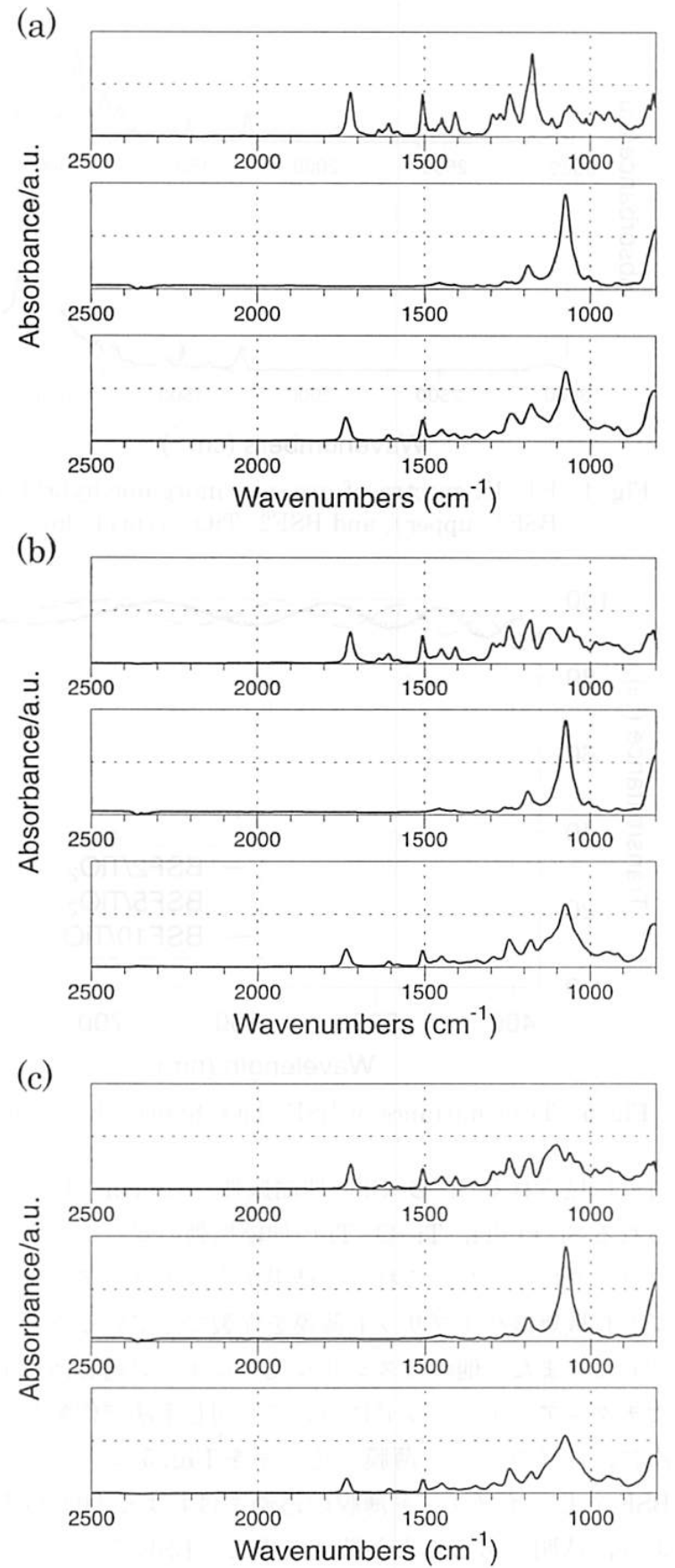

Fig. 1 FT-IR spectra of (a) EO2 (upper), MPTMS (middle), BSF2 (lower), (b) EO5 (upper), MPTMS (middle), BSF5 (lower), (c) EO10 (upper), MPTMS (middle), BSF10 (lower).

芳香環が等方的であるため, 低複屈折の特徴を示すことか ら，分極率の高い芳香族の中であ様々な用途が期待されて (る ${ }^{14 \sim 17)}$ 。本検討においては 2 つのアクリル基を有する ビスフェニルフルオレンアクリレートの末端にアルコキシ シリル基を導入することでチタンアルコキシドに対して結 合性をむつデュアルサイト型シランカップリング斉である ビスシリル化フルオレン誘導体を合成した。

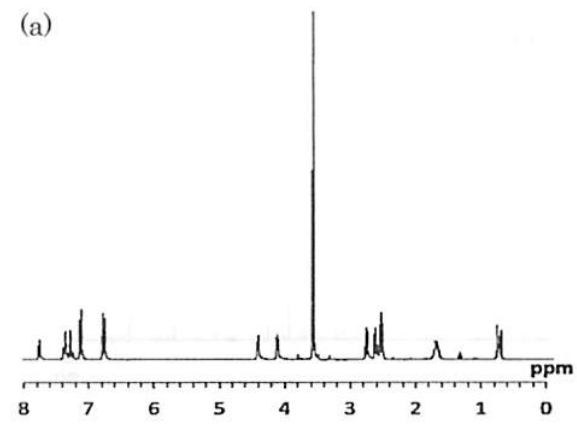

(b)
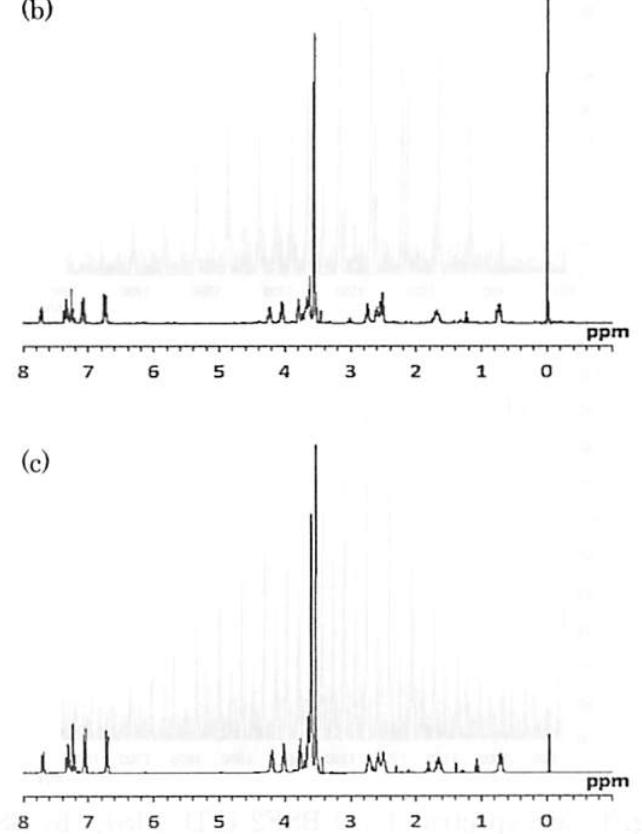

Fig. $2{ }^{1} \mathrm{H}-\mathrm{NMR}$ spectra of (a) BSF2, (b) BSF5, and (c) BSF10.

反応の進行は，赤外スペクトルで確認した。BSF2 は， Fig. 1 (a) に示すように, EO2 のスペクトルで見られてい た $1630 \mathrm{~cm}^{-1}$ 付近の $\mathrm{C}=\mathrm{C}$ 基の吸収に由来するピークが消 失し, MPTMSで見られていた $2840 \mathrm{~cm}^{-1}, 1100 \mathrm{~cm}^{-1}$ 付 近の $\mathrm{Si}-\mathrm{OMe}$ 基の吸収に由来するピークが BSF2 のスペ クトルであ見られていることから反応の確認ができた。 Fig. 2 (a) に示した BSF2 の ${ }^{1} \mathrm{H}-\mathrm{NMR}$ スペクトルでは, $\delta(\mathrm{ppm})=0.6 \sim 0.8\left(\mathrm{CH}_{2}-\mathrm{CH}_{2}-\mathrm{Si}, \mathrm{t}, 4 \mathrm{H}\right), \quad 1.6 \sim 1.8$ $\left(\mathrm{CH}_{2}-\mathrm{CH}_{2}-\mathrm{CH}_{2}, \mathrm{~m}, 4 \mathrm{H}\right), 2.4 \sim 2.6\left(\mathrm{~S}-\mathrm{CH}_{2}, \mathrm{t}, 4 \mathrm{H}\right)$, $2.6\left(\mathrm{CH}-\mathrm{CH}_{2}-\mathrm{CH}_{2}, \quad\right.$ t, $\left.4 \mathrm{H}\right), 2.6 \sim 2.8\left(\mathrm{CH}-\mathrm{CH}_{2}\right.$, t, $4 \mathrm{H}), \quad 4.0 \sim 4.2\left(\mathrm{CH}-\mathrm{O}-\mathrm{CH}_{2}, \mathrm{t}, 4 \mathrm{H}\right), 4.2 \sim 4.4(\mathrm{Ar}-$ $\left.\mathrm{O}-\mathrm{CH}_{2}, \mathrm{t}, 4 \mathrm{H}\right), 6.6 \sim 7.8(\mathrm{Ar}-\mathrm{H}, \mathrm{m}, 16 \mathrm{H})$ となっ た。 $\mathrm{OMe}$ 基に由来するピークと新規の $\mathrm{S}-\mathrm{CH}_{2}-\mathrm{CH}_{2}-\mathrm{C}=\mathrm{O}$ に由来するピークが見られ, Michael 付加反応の進行が確 認できた。BSF2 の分子量は計算值が 938.3 であるのに対 L, Fig. 3 (a) の FD-MS の測定值が 938.6 であり, 構造 決定に慗がった。BSF5 と BSF10についても，FT-IR と ${ }^{1} \mathrm{H}-\mathrm{NMR}$ スペクトルにおいて同様の測定結果が得られた ((Fig. 1 (b), (c), Fig. 2 (b), (c))。BSF5 と BSF10 の FAB 

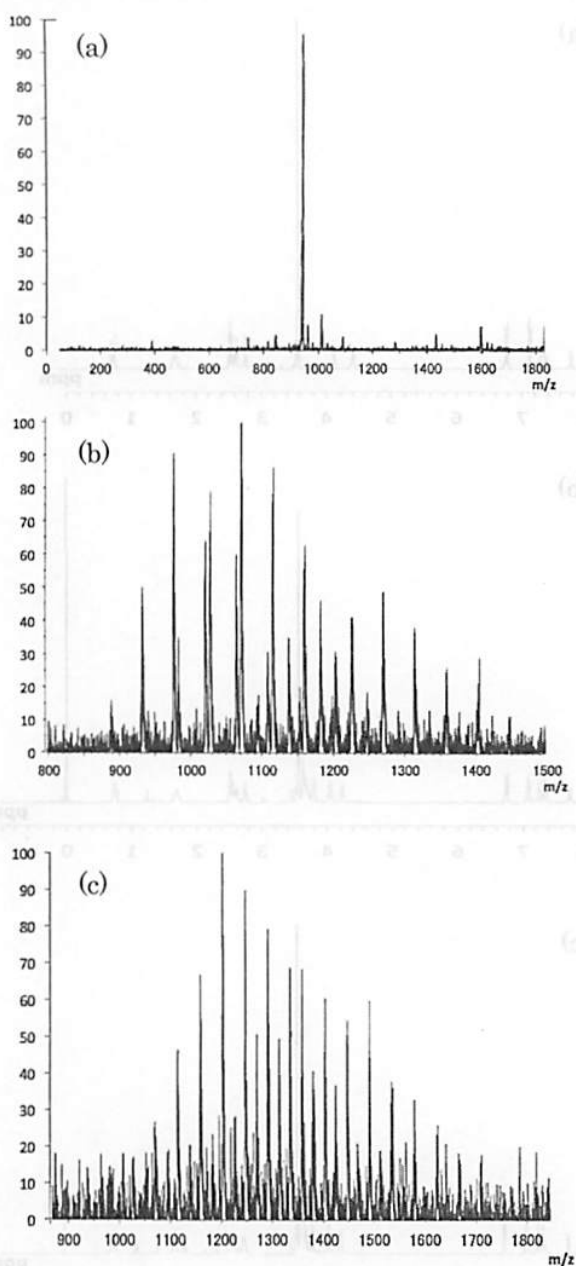

Fig. 3 MS spectra of (a) BSF2 (FD-MS), (b) BSF5 (FAB-MS), and (c) BSF10 (FAB-MS).

-MS 測定の結果，BSF5 では計算值の分子量 1073.4 に対 して測定值 1071.0 が確認され，BSF10 では計算値 1298.6 に対して測定值 1291.9 が確認された（Fig. 3 (b)，(c))。 また, フラグメントにはエチレンオキサイド単体の分子量 45.06 が観測された。以上の測定結果より BSF2, BSF5, BSF10 の構造を決定した。

\section{2 フルオレンーチタニアハイブリッドの物性}

ソルーゲル法により作製した有機無機ハイブリッドは, 有機成分と無機成分を均一化することにより界面を持たな いナノ構造体として形成されている。したがって，それは 屈折率差による散乱が起こらない光学的に透明な材料を作 製することができる。合成したビスシリル化フルオレン誘 導体は, 末端にアルコキシシリル基が導入されており, チ タンアルコキシドとのハイブリッド化が可能である。Fig. 4 に BSF2 と作製したハイブリッド薄膜との FT-IR スペク トルを比較し, 加水分解重縮合の進行を確認した。加水分 解重縮合が進むに伴い， $2840 \mathrm{~cm}^{-1}$ と $1080 \mathrm{~cm}^{-1}$ 付近に見 られる $\mathrm{Si}-\mathrm{O}-\mathrm{Me}$ 基の吸収が減少した。さらに, $1040 \mathrm{~cm}^{-1}$

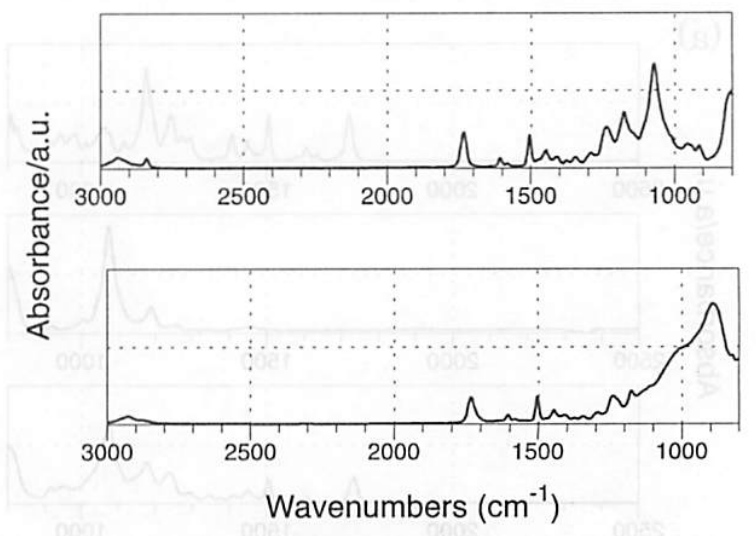

Fig. 4 FT-IR spectra of organic-inorganic hybrid of $\mathrm{BSF} 2$ (upper), and $\mathrm{BSF}_{2}-\mathrm{TiO}_{2}$ hybrid (lower).

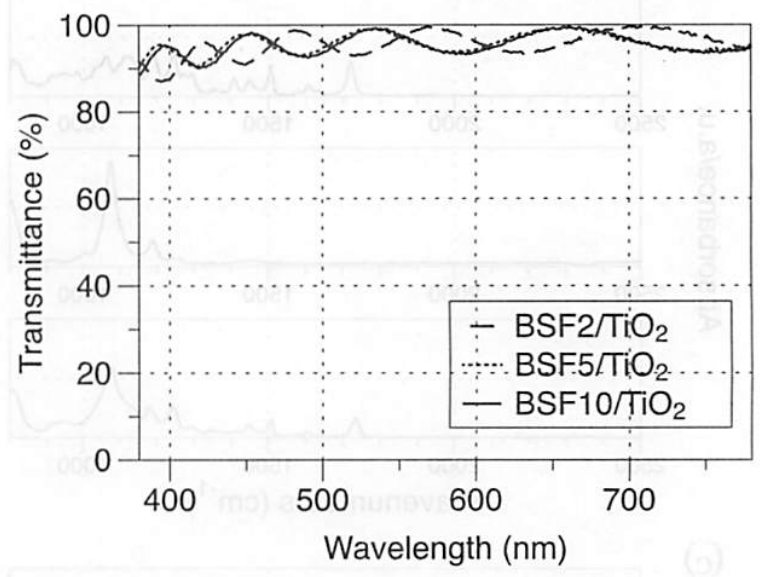

Fig. 5 Transmittance of $\mathrm{BSF}-\mathrm{TiO}_{2}$ hybrid thin films.

付近に見られる $\mathrm{Si}-\mathrm{O}-\mathrm{Si}$ の伸縮振動, $920 \mathrm{~cm}^{-1}$ 付近に見 られる $\mathrm{Si}-\mathrm{O}-\mathrm{Ti}, \mathrm{Ti}-\mathrm{O}-\mathrm{Ti}$ の伸縮振動のピークが重なり ブロードになった。これらの結果から, チタニアーフルオ レン有機無機ハイブリッド薄膜を作製できていることを確 認した。また，他のビスシリル化フルオレン誘導体を用い たチタニアハイブリッドについてあ同じ手法で作製した。 次に，ハイブリッド薄膜の透過率を Fig. 5 に示す。どの BSF でむハイブリッド薄膜の透過率はおよそ $90 \%$ 以上で あり，透明であることが確認できた。BSFごとでクラッ クの発生しないチタニアの最大含有量が異なり, BSF2 で

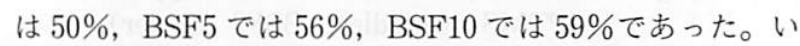
ずれも最大含有量以上の $\mathrm{TiO}_{2}$ 濃度でクラックが発生した。 クラックはソルーゲル反応による硬化収縮で生じ，無機成 分の組成比が多い場合，収縮率が大きいことで発生する。 BSF ではエチレングリコールユニットの増加に応じて有 機マトリックスの柔軟性が向上したため，収縮を緩和し， $\mathrm{TiO}_{2}$ 含有量の限界值を上げることができたと推測される。 Fig. 6 には, 反射分光膜厚計で測定したハイブリッド膜の 屈折率を示す。BSF2, BSF5, BSF10 の単独硬化物は, BSF2 の 1.6 に対し BSF10 では 1.55 まで低下する。これ はエチレングリコールユニットの増加に応じた屈折率の低 


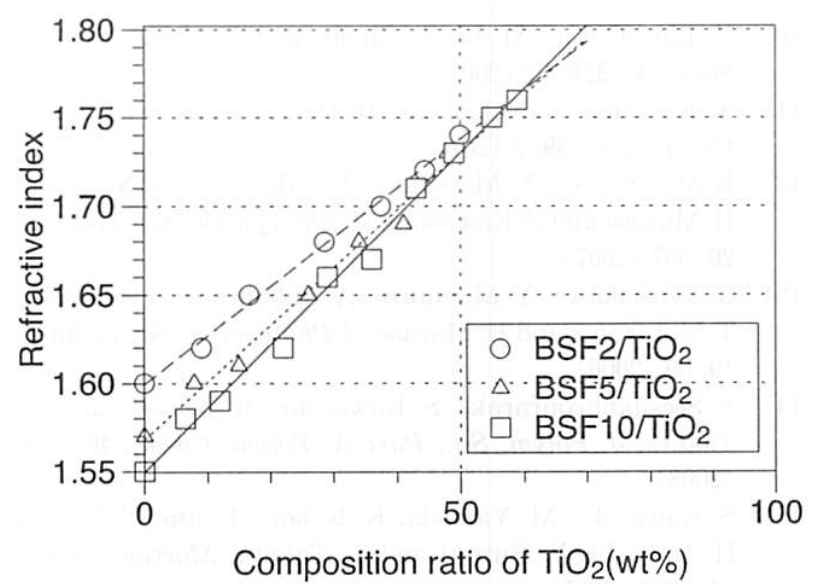

Fig. 6 Refractive index of organic-inorganic hybrid thin films of $\mathrm{BSF} 2-\mathrm{TiO}_{2}$ hybrid, $\mathrm{BSF} 5-\mathrm{TiO}_{2}$ hybrid, and $\mathrm{BSF} 10-\mathrm{TiO}_{2}$ hybrid.

下である。しかし，ハイブリッド薄膜の屈折率を比較する と，チタニア組成がおよそ $50 \mathrm{wt} \%$ の場合に屈折率は 1.73 から 1.74 で同程度になった。一般的にハイブリッド材料 の屈折率は有機成分とチタニアの体積分率で決まるため, $\mathrm{TiO}_{2}$ が $0 \%$ の場合はそれぞれの $\mathrm{BSF}$ の屈折率で, $\mathrm{TiO}_{2}$ が $100 \%$ の場合は $\mathrm{TiO}_{2}$ の屈折率を示し, $\mathrm{TiO}_{2}$ 含有量に応 じて直線的に变化する。そのため，それぞれのハイブリッ ドの屈折率の変化のグラフが交差することはないはずであ る。しかし，50wt\%付近でそれぞれのハイブリッドの屈 折率が交差し, BSF10 から作製したハイブリッド膜の屈 折率が大きくなる傾向が見られた。この原因は, 薄膜中の 空隙の存在割合が異なることに起因していると推測される。 すなわち, BSF はカルド構造より鎖長が伸びた分子であ り，2つのアルコキシシリル基の間にスペースが生じる。 BSF2 ではチタニアを取り込めるに十分なスペースがない
が, BSF5, BSF10ではチタニアを取り込めたと考えられ る。特に, BSF10では大きなスペースを形成できたと推 測される。BSF 末端のアルコキシシリル基とチタンブト キシドが結合するので，閉環した側鎖構造を作ると仮定す ると，Fig. 7 に示すように, BSF10ではかなり大きなス ペースをもたらすことが予想され，チタニアを取り込むと ともに, 屈折率低下の要因となる空隙を減らしたものと考 えられる。さらに, 側鎖のエチレングリコールユニットが ゾルーゲル法で作製したチタニアを安定化する効果む寄与. していると推察できる。

\section{4. 結 言}

高屈折率な有機無機ハイブリッドを作製するために，ビ スフェニルフルオレン骨格の側鎖末端にアルコキシシリル 基を有するビスシリル化フルオレンを合成した。これらの シランカップリング剤を用いたチタニアハイブリッドはソ ルーゲル反応によって調製した。得られた有機無機ハイブ リッドは, 高いチタニア含有量でも透明薄膜を作り出すこ とができ, 八イブリッド薄膜のクラックのない範囲は, シ ランカップリング剤の側鎖に存在するエチレングリコール ユニットの数に依存して変化することが確認された。シラ ンカップリング斉の屈折率は, ビスフェニルフルオレンを 導入することによって 1.60 に近い高い值を示した。また， チタニアとのハイブリッド化において, 屈折率は 1.60 か ら 1.80 までの間で制御することができた。

\section{謝辞}

本研究は, 文部科学省科学研究費補助金新学術領域研究 「元素ブロック高分子材料の創出」(領域番号 2401)/課題 番号 24102010 を受けて行われた。
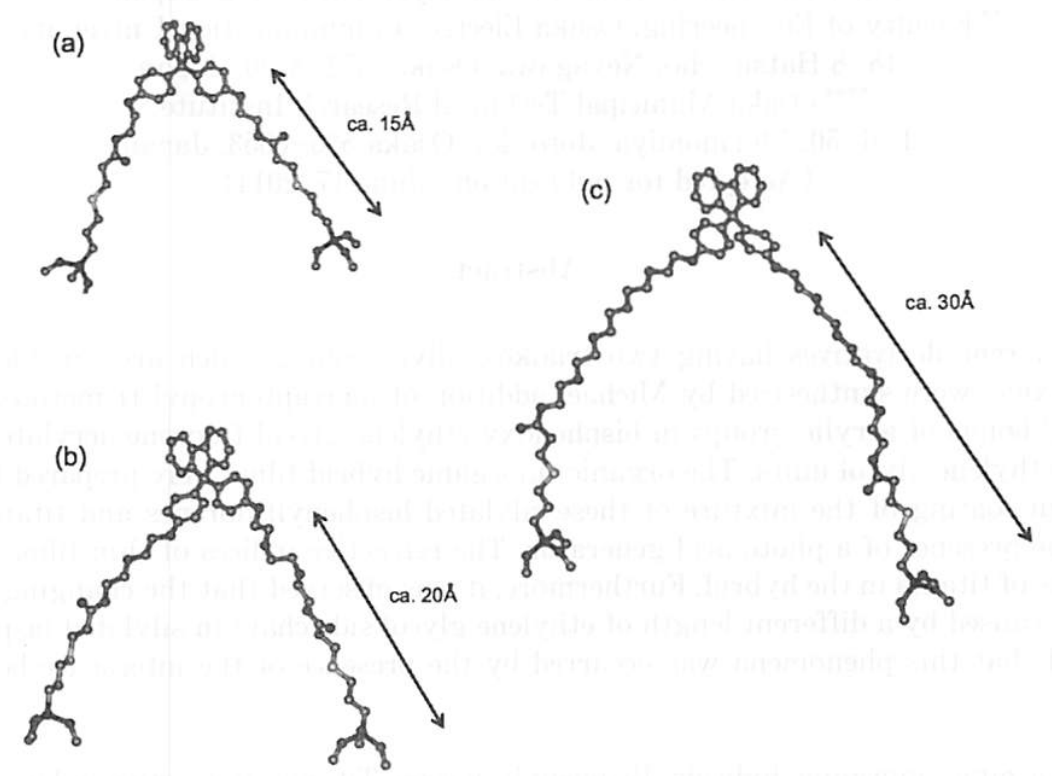

Fig. 7 Length of terminal side chain of (a) BSF2, (b) BSF5, and (c) BSF10 


\section{文献}

1) B. Wang, G. L. Wilkes, J. C. Hedrick, S. C. Liptak and J. E. McGrath, Macromolecules, 24, 3449 (1991).

2) J. Zhang, S. Luo, L. Gui, J. Mater. Sci., 32, 1469 (1997).

3) B. -T. Liu, S-. Tang, Y.-Y. Yu and S. - H. Lin, Colloids Surf., A., 377, 138 (2011).

4) Y.-Y. Yu and H.-H. Yu, Thin Solid Films, 529, 195 (2013).

5) B.-T. Liu and P.-S. Li, Surf. Coat. Tech., 231, 301 (2013).

6) F. Wang, Z. Luo, S. Qing, Q. Qiu and R. Li, J. Alloys Compd., 486, 521 (2009).

7) J. L. H. Chau, Y.-M. Lin, A.-K. Li, W.-F. Su, K.-S. Chang, S. L.-C. Hsu and T.-L. Li, Mater. Lett., 61, 2908 (2007).

8) S. Wu, G. Zhou and M. Gu, Opt. Mater., 29, 1793 (2007).

9) Y.-Y. Yu and H.-H. Yu, Thin Solid Films, 529, 195 (2013).
10) Y. Liu, C. Lii, M. Li, L. Zhang and B. Yang, Colloids Surf., A., 328, 67 (2008).

11) Y. Koyama, K. Nakazono, H. Hayashi and T. Tataka, Chem. Lett., 39, 2 (2010)

12) K. Matsukawa, Y.Matsuura, A. Nakamura, N. Nishioka, H. Murase and S. Kawasaki, J. Photopolym. Sci. Technol., 20, 307 (2007).

13) K. Matsukawa, Y.Matsuura, A.Nakamura, N. Nishioka, T. Motokawa and H. Murase, J.Photopolym. Sci. Technol., 19, 89 (2006)

14) S. Seesukphronrarak, S. Kawasaki, K. Kobori and T. Takata, J. Polym. Sci., Part A, Polym. Chem., 46, 2549 (2008).

15) S. Kawasaki, M. Yamada, K. Kobori, F. Jin, Y. Kondo, H. Hayashi, Y. Suzuki and T. Takata, Macromolecules, 40, 5284 (2007).

16) Z. Hu, S. Li and C. Zhang, J. Appl. Polym. Sci., 106, 2494 (2007).

17) Z. Hu, S. Li and C. Zhang, J. Appl. Polym. Sci., 107, 1288 (2008)

\title{
$<$ Original Paper $>$
}

\section{Preparation of Terminal Silylated Bisphenylfluorene/Titania Thin Films and the Influence of Side-chain Length on Their Refractive Indices}

\author{
Yuki MINAMI *,**, Takuma YOSHIMOTO ***, Noboru NISHIOKA ***, \\ Seiji WATASE ${ }^{* * * *}$ and Kimihiro MATSUKAWA ${ }^{*}, * * *, * * * *$ \\ * Osaka City University \\ 3-3-138 Sugimoto, Sumiyoshi-ku, Osaka 558-8585, Japan \\ ** SOLAR CO., Ltd. \\ 1174-1 Nakano-cho, Kasai-shi, Hyogo 675-2102, Japan \\ *** Faculty of Engineering, Osaka Electro-Communication University \\ 18-8 Hatsu-cho, Neyagawa, Osaka, 572-8530, Japan \\ **** Osaka Municipal Technical Research Institute \\ 1-6-50, Morinomiya, Joto-ku, Osaka 536-8553, Japan \\ (Accepted for publication: June 17, 2014)
}

\section{Abstract}

Bisphenylfluorene derivatives having two trialkoxysilyl groups, which are capable to bond with titanium alkoxide, were synthesized by Michael addition of mercaptopropyl trimethoxysilane to two terminal $\mathrm{C}=\mathrm{C}$ bonds of acrylic groups in bisphenoxy ethylene glycol fluorene acrylate having different length of ethylene glycol units. The organic-inorganic hybrid films were prepared by UV irradiation, after spin coating of the mixture of these silylated bisphenylfluorenes and titanium tetra- $\mathrm{n}^{-}$ butoxide in the presence of a photo acid generator. The refractive indices of thin films were depended on the contents of titania in the hybrid. Furthermore, it was observed that the changing rate of refractive index was caused by a different length of ethylene glycol side chain in silylated bisphenylfluorene. It was seemed that this phenomena was occurred by the presence of the interspace between the two side chains.

Key words : Organic-inorganic hybrids, Bisphenylfluorene, Titania, Refractive index

(Received : June 2, 2014) 